tively later, and the bottoms of the spires to an earlier stage than the corresponding mean time of spinning on a plane tablet.

Now if the pencil is hard, so that its circular edge remains nearly constant in radius, the envelope of the cycloido-spirals will consist of two straight lines converging at the point where the top would cease to rotate if the other conditions of motion remained similar. In other words, supposing the period of precession to be nearly constant, the angular velocity of the top would vanish at the point of intersection in question. The cause of the gradual cessation of motion here, as in case of the horizontal tablet, is friction; but in case of the oblique tablet, if the period of percession remains nearly constant, the crests of the spires correspond to smaller angular velocities, and will therefore have smaller radii of curvature than the troughs of the spires where angular velocity passes through a maximum. In other words, the loops will be less obtuse at the top and more obtuse at the bottom of the dip. Part of the energy of rotation is periodically potentialized. To draw such curves the top must necessarily move across the dip.

If the end of the pencil is convex, so that the rolling on the pivot is relatively decreased as the top rises, the envelope of the spires will no longer be straight, but consist of two converging curved lines as shown in the figure.

In the preceding instances the direction of the progressive motion of the top, i. e., the trend of the 'cornucopias,' is nearly a straight line at right angles to the dip. Suppose, however, that for the plane tablet a flat conical one be substituted, which may be either raised or depressed in the center. The dip is now everywhere radial. In this case the progressive motion of the top becomes orbital around the axis of the cone, if the dip be suitably chosen. We have then a very simple arrangement for simula- ting (except, of course, as to cause, and quantity) the orbital and precessional motion of the earth. Indeed, beautiful fluted curves corresponding to nutational movement may also easily be obtained by slightly destroying the balance of the top, though this interferes somewhat with the smoothness of motion.

C. Barus.

Brown University, Providence.

\section{MEETING OF THE MAZAMAS AT CRATER LAKE, OREGON.}

The annual field meeting of the 'Mazamas,' a club of mountain climbers with headquarters at Portland, Oregon, was held at Crater Lake, in the Cascade Mountains, during the latter part of August. This meeting was one of the most important and successful ever held and was a memorable one in many ways. Through the cooperation of local Crater Lake clubs, of Ashland, Medford and Klamath Falls, about 500 persons were present. There were also present members of four of the scientific bureaus of the government. The various parties arrived from the 14th till the 19th, and the camp began to break up about the 25 th.

The Mazamas pitched their tents on an eminence overlooking the wonderful crater, and meetings were held evenings around a huge bonfire in front of the tents. On the evening of August 21st the ancient volcano, whose summit is occupied by Crater Lake, was christened Mt. Mazama. An appropriate address was read by the President, Mr. C. H. Sholes, of Portland. This was followed by a dedicatory poem by the VicePresident, Miss Fay Fuller, of Tacoma, Washington. Then the energetic Secretary, Rev. Earl M. Wilbur, of Portland, acting as 'toastmaster,' introduced the following toasts: To Mt. Mazama, responded to by Mr. J. S. Diller, of the U. S. Geological Survey; to the Poetry of Crater Lake, by Capt. Oliver Applegate, of Klamath 
Falls; to the Forests of Crater Lake, by Dr. C. Hart Merriam, Chief of the U. S. Biological Survey ; to 'That Tired Feeling,' by Prof. B. W. Evermann, of the U. S. Fish Commission ; to the History of the Cascade Mountain National Forest Reservation, by Mr.W.G. Steel, of Portland, late President of the Mazamas. At the conclusion of the exercises a signal gun was fired and the crater of Wizard Island, a cinder cone rising 840 feet from the water of the lake, was illuminated by burning 20 pounds of ' red fire.'

On other evenings informal ' camp fire talks' were given by the government scientists present. Mr. J. S. Diller, of the Geological Survey, gave an account of the geological history of Crater Lake. Mr. F. V. Coville, Chief Botanist of the Department of Agriculture, spoke of the flora of the region and mentioned many facts of historic interest connected with early botanical explorations in the Northwest. Dr. C. Hart Merriam spoke on the fauna of the region and the geographic distribution of life in Oregon with special reference to the Cascade Range. Prof. B. W. Evermann, of the Fish Commission, spoke of the animal life of Crater Lake and its physical features with reference to the introduction of fish.

The government is doing a great deal of scientific work in Oregon this year. Mr. Diller is mapping the distribution of volcanic rocks in the Cascade Range and Rogue River Valley; Mr. 'F. V. Coville and his assistant, Mr. John Lieberg, have conducted extensive botanical explorations across the State; Dr. C. Hart Merriam, assisted by Meșsrs. Vernon Bailey, E. A. Preble, C. P. Streator and C. Allen, has carried the work of the biological survey over the greater part of Oregon ; and Prof. B. W. Evermann, assisted by Prof. Cox, is engaged in studying the fish faunas of numerous waters in the Northwest. The officers in charge of these several parties were glad to avail them- selves of the exceptionally favorable opportunity to study the natural history of the Crater Lake region afforded by the Mazama excursion. Two new boats were built and placed on the lake, and numerous courtesies were extended to the government men by the Mazamas.

Crater Lake is easily the jewel of the Northwest. It is hoped that means of reaching it will be perfected in the near future, so that it may be visited by the thousands of tourists and others who now content themselves with the Grand Cañon of the Colorado, the Yellowstone Park and the Yosemite. It can now be reached by good wagon roads from Ashland, Medford and Klamath Falls, but there are no regular conveyances or stopping places.

Crater Lake is a beautiful sheet of indigoblue water, about 6 miles in length by $4 \frac{1}{2}$ in breadth. It occupies the crater or caldron of an extinct volcano and is completely surrounded by a precipitous wall, varying from 1,000 to something over 2,000 feet in height. A remarkably perfect and symmetrical cinder cone with a crater at its summit forms an island-Wizard Island -which rises 840 feet above the surface of the lake. The lake was sounded by Major C. E. Duttion in 1886 and found to be 2,000 feet in greatest depth. Its surface temperature is $59^{\circ}$ or $60^{\circ} \mathrm{Fahr}$. The altitude of the rim of the crater varies from about 7,000 to 8,200 feet.

Crater Lake Mountain is covered with a magnificent forest of conifers, arranged in well marked belts or zones, from base to summit. Beginning at the bottom (in the Transition Zone) is a relatively open forest of huge yellow pines (Pinus ponderosa), some of which measure 22 feet in circumference. Mixed with these are some sugar pines (Pinus lambertiana) and cedars (Libocedrus decurrens). At an altitude of about 5,000 feet, on the south and southwest slopes, the yellow pines give place to a 
dense forest of the lodge pole, or Murray pine (Pinus murrayana), more or less mixed with Douglas spruce (Pseudotsuga taxifolia), white fir (Abies concolor) and white pine (Pinus monticola). This belt is invaded by the hemlock (Tsuga pattoniana), and redbark fir (Abies nobilis) of the zone above. At about 6,200 feet the trees of the middle or Canadian Zone fail, except on the warmer exposures, and one enters the superb forest of the Hudsonian or upper zone, a forest of splendid firs (Abies nobilis), and sombre hemlocks (Tsuga pattoniana), sparingly mixed with the sub-alpine fir (Abies lasiocarpa) and white-bark pine (Pinus albicaulis). The monstrous cones of the redbark fir, with their bright red seed wings and exserted bracts, are among the wonders of the vegetable kingdom; while the dark hemlocks, with their drooping branches draped in the long hanging beards of a blackish lichen, rank among the giants, some of their trunks measuring $17 \frac{1}{2}$ feet around.

The Columbia black-tail deer (Cariacus columbianus) is common on the mountains and furnished our camp with fresh meat. Large trout abound in Klamath Lake, at the south foot of the Mountain, and afford excellent fishing. Klamath Lake is also the resort of thousands of ducks and other waterfowl. Hence the sportsman, as well as the tourist, naturalist, and lover of the grand and beautiful in Nature, is sure to find the Crater Lake region a place of unusual interest. For scenic beauty and grandeur Crater Lake, with its deep blue waters walled in by towering cliffs and rugged crags, ranks among the gems of American scenery.

C. H. M.

\section{CURRENT NOTES ON PHYSIOGRAPHY.} DRUMLINS IN SWITZERLAND.

Dr. J. FrüH, of Zurich, gives an account of 'Die Drumlins Landschaft' - following by over twenty years Desor's Paysage morain- ique - with especial reference to the Alpine foreland (Jahresber. St. Gall. naturwis. Gesellsch., 1896). After a serviceable review of the distribution and description of drumlins in other countries, especially Ireland and the United States, the author describes in detail a number of localities, from Lake Constance to the Reuss. Not until 1893 were drumlins recognized in the Alpine foreland; Sieger, then describing a group of them on the peninsula between the two arms of Lake Constance (RichthofenFestschrift). It now appears that the Piedmont area overspread by the Rhine glacier in the latest glacial epoch contains a large number of radially arranged drumlins, whose attitude confirms the divergent direction of ice movement indicated by the dispersal of certain peculiar boulders in a district where striæ are almost wanting. The broad spreading of the glacier on the Piedmont area is shown by the deflection of the drumlins on the extreme right and left of Lake Constance, about $80^{\circ}$ from the axis of the lake. The finest drumlin landscape of Switzerland is said to be a little south Pfäffikon, northeast of Lake Zurich, in the district of the Limmat glacier. Früh advocates the subglacial origin of drumlins, comparing them to sandbanks in rivers, as have other authors, but recognizing that some difficulties attend this explanation. In certain localities, the drumlins appear to be formed of overriden moraines.

\section{TOPOGRAPHY OF SOUTHERN TUNIS.}

Capt. E. de Larminat, of the geographical service of the French army, makes an interesting study of topographic forms in southern Tunis (Ann. de Géogr., v., 1896, 386-406). The initial form of the region appears to have been an extensive anticlinal dome; but this is now broadly unroofed. A ridge with an infacing escarpment, maintained on a resistant stratum, encloses an inner lowland, eroded on 